\title{
Practical research on the cultivation of college students' innovation and entrepreneurship ability based on undergraduate training program for innovation and entrepreneurship
}

\author{
DOI: $10.46932 / \mathrm{sfjdv} 3 \mathrm{n} 1-125$
}

Received in: January $20^{\text {th }}, 2022$

Accepted in: February $1^{\text {st }}, 2022$

\section{Yinping Chen}

Institution: School of Marxism, Shandong Technology and Business University, Yantai, China Address: China, Shandong, Yantai, Penglai, S Ring Rd, 滨海中路 191 号 邮政编码: 265600 E-mail: cyp0711@163.com

\section{Fenggang Lu}

Institution: School of Public Administration, Shandong Technology and Business University, Yantai, China

Address: China, Shandong, Yantai, Penglai, S Ring Rd, 滨海中路 191 号 邮政编码: 265600

E-mail: 1fg0202@163.com

\begin{abstract}
The undergraduate training program for innovation and entrepreneurship is an important measure of Ministry of Education of the People's Republic of China to reform the talent training model. The undergraduate training program for innovation and entrepreneurship has been carried out for six years, which improves that it can be conducive to cultivating students' innovation consciousness and innovative thinking, as well as promoting students' abilities of independent learning, planning and future employability.
\end{abstract}

Keywords: undergraduate training program for innovation and entrepreneurship, innovation and entrepreneurship ability, learning ability, employability.

\section{INTRODUCTION}

Since 2007, the ministry of education has started to implement the "innovative experiment plan for college students". Since 2011, the ministry of education has added college students' entrepreneurship training and entrepreneurship practice projects on the basis of the "innovative experimental program for college students" and started to implement the "undergraduate training program for innovation and entrepreneurship", which is an important part of the "quality project" of undergraduate education. It aims at promoting the transformation of education ideas in colleges and universities, reforming personnel training mode, mobilizing students' initiative, enthusiasm and creativity, strengthening the training of innovation and entrepreneurship ability, enhancing students' innovation ability and entrepreneurship ability on the basis of innovation, and cultivating high-level innovative talents adapted to the construction of an innovative country. 


\section{THE BASIC SITUATION OF OUR UNIVERSITY STUDENTS' INNOVATION AND} ENTREPRENEURSHIP TRAINING PROGRAM

As the first multi-discipline business university in China, our university was selected by the ministry of education in 2012 and became one of the first provincial universities in Heilongjiang province to implement the national undergraduate training program for innovation and entrepreneurship.

Since 2012, our school has been approved 216 national projects, 345 provincial projects, 591 schoollevel projects, and the number of national and provincial project projects approved has steadily increased, covering 60 undergraduate majors and at least 10 grades. Students. The research results have published more than 1,200 papers in academic journals at or above the provincial level, including 18 national core journals; More than 50 patents were applied for. At the same time, through the demonstration effect of the college students 'innovation and entrepreneurship training program project, each teaching unit uses the creation project as the basis to cultivate outstanding scientific and technological competition results.

\section{THE ROLE OF THE UNDERGRADUATE TRAINING PROGRAM FOR INNOVATION AND ENTREPRENEURSHIP IN CULTIVATING THEIR ABILITY OF INNOVATION AND ENTREPRENEURSHIP}

The undergraduate training program for innovation and entrepreneurship has been carried out in our school for six years. Through the results obtained by students participating in the project and the changes of students' ability before and after the project, students' innovation and entrepreneurship ability has been improved to different degrees.

\section{MIT IS CONDUCIVE TO CULTIVATING STUDENTS' INNOVATIVE CONSCIOUSNESS AND INNOVATIVE THINKING}

The development of undergraduate training program for innovation and entrepreneurship requires students to raise questions and find solutions through research, experiment or practice. This process exactly cultivates college students' awareness of innovation and innovative thinking. In the process of carrying out the college students' innovation and entrepreneurship training program, students generally feel that they have gradually developed the habit of independent thinking, and their ability to research and analyze problems can be improved. They are bold and cautious in the research process. At the same time, in the process of project implementation, gradually mastered the methods of scientific research, formed the good habits of scientific research, inspire the innovation consciousness, cultivate the ability to analyze and solve problems, and through the software development and physical production, publication, patent applications, widely to improve students' innovative ability, the effect is remarkable. 


\section{IT PROMOTES THE IMPROVEMENT OF STUDENTS' INDEPENDENT LEARNING}

\section{ABILITY}

The development of the project is not simply the application of a certain knowledge point or a certain professional course knowledge, but requires the students to integrate the knowledge they have learned and study the unknown knowledge. This process helps develop students' habit of independent learning. Improve students' independent learning ability.In the process of participating in college students' innovation and entrepreneurship training program, students clearly feel the deficiency of existing knowledge reserve and the narrow scope of knowledge. They discover deficiencies through the project research process, and then keep learning. In the process of learning, they combine the knowledge acquired through discussion, analysis and summary. "One of our most valuable lessons is the feeling of being able to swim in the ocean of knowledge." This is the student after participating in the undergraduate training program for innovation and entrepreneurship.

\section{IT PROMOTES THE IMPROVEMENT OF STUDENTS' PLANNING ABILITY}

Undergraduate students are the subject of the undergraduate training program for innovation and entrepreneurship. The entire research process from the topic selection and application of the project to the project approval requires the research team to complete by themselves, and the role of teachers is only to guide them. Especially in the process of project, the team needs to determine the time distribution of the research, according to the division of labor coordination team members personal special skill, need more study of the problems existing in the research process timely adjustment scheme, all of this is helpful to improve students for their own learning, career and life planning ability, in order to set up the correct learning view, professional view and outlook on life.

\section{IT PROMOTES THE IMPROVEMENT OF STUDENTS' FUTURE EMPLOYMENT ABILITY}

The undergraduate training program for innovation and entrepreneurship is proposed by the ministry of education for the lack of practical teaching in current college students' education. Students participating in the "undergraduate training program for innovation and entrepreneurship " need to have two knowledge structures. Firstly, it needs professional basic knowledge related to the undergraduate training program for innovation and entrepreneurship. Secondly, it needs entrepreneurship knowledge. With the development of the project, most students have a good grasp of the basic knowledge of their major and can apply it in the project implementation. In the process of application, I am also constantly skilled in my professional knowledge and application in practice, which can also enhance my ability to operate professional skills. Members in different professional background, through the communication to analyze 
the various views, can form a relatively comprehensive understanding, at the same time, the professional communication between can promote the expansion of college students in knowledge, not only in the professional knowledge of the blind area, to realize the transformation and development of theoretical knowledge. The development of college students' innovation and entrepreneurship training program is not limited to the expansion of knowledge and proficiency of skills, but also the accumulation of practical experience in the process of project practice, improving comprehensive ability and employment quality, laying a good foundation for the future work.

According to the graduates feedback tracking feedback and unit of choose and employ persons, too much during the period of school to participate in a project or other students scientific research training, the practice ability and plasticity are particularly strong, find favor with the unit of choose and employ persons, employment to have satisfactory unit for students, and soon grow into industry backbone or business elite, is well received by society.

\section{CONCLUSIONS}

The undergraduate training program for innovation and entrepreneurship has a wide range of contents, especially for undergraduates in ordinary universities. It is a rare opportunity to participate in scientific research projects, and they can participate in competitions or start their own businesses based on the research results to cultivate innovative thinking and entrepreneurship awareness. As a university and a university teacher, they should take it as an important content of teaching and not just as a form. They should guide, discover and explore the innovative thoughts of undergraduates, cultivate their innovative consciousness and further improve their innovative ability through the implementation of the training program for innovation and entrepreneurship of undergraduates.

\section{ACKNOWLEDGMENTS}

The authors thank the support of research projects, Shandong key R\&D project (2021RKY0713), SDTBU wealth management fund (2019ZBKY055), SDTBU doctoral fund (BS202006, and National Social Science Fund (21ZDA116). 


\section{REFERENCES}

[1] Shuting Li, Mian Lu, Xunjie Liang, Suoyi Huang. the Effect of the Undergraduate Training Program for Innovation and Entrepreneurship on Cultivation of College Students' Ability [J]. Studies of Trace Elements and Health, 2018, (2):68-69.

[2] Qiufeng Wei, Suoyi Huang, Yulin Zhou, Wenning Ling, Jingying Huang, Li Huang. Research on the Cultivation of College Students' Innovation Ability Based on the Undergraduate Training Program for Innovation and Entrepreneurship [J]. Studies of Trace Elements and Health, 2017,(6):61-63.

[3] Ding-er Liu. Practical Research on the Cultivation of Undergraduates' Innovation Ability with the Project as the Carrier [J]. Manager Journal, 2017,(17): 349-350.

[4] Yinping Chen, Xiaohong Sun, Liucheng Zhang, Long Yin. Practice and Exploration of the Undergraduate Training Program for Innovation and Entrepreneurship [J]. Journal of Science and Technology Economic Market, 2015,(1):118-119.

[5] Vasco-Morales, S. Toapanta-Pina, P. Obstetrics Student Satisfaction with the Use of Video Channels as a Support Method in the Learning Process[J]. South Florida Journal of Development, 2021, 2(1):985992. 